\title{
Między Goebbelsem a Stalinem. O propagandzie prawa w Polsce 1944-1947
}

Wydawnictwo Naukowe Scholar w Warszawie wydało w 2020 r. książkę Jarosława Kuisza, pt. Propaganda bezprawia. O „popularyzowaniu prawa” w pierwszych latach Polski Ludowej ${ }^{1}$. Ta obszerna monografia jest dla historyka prawa bardzo nietypowa. Autor podjął się dokonania opisu oraz analizy „wybranych aspektów" propagandy prawa w początkach Polski Ludowej. Pod pojęciem prawa (zawartym m.in. w tytule całości) rozumie on także państwo, zagadnienia ustrojowe. Przedmiotem analizy stały się dla Autora materiały oficjalne kierowane do społeczeństwa z zamiarem oddziaływania propagandowego. Jarosław Kuisz $\mathrm{w}$ zasadzie do minimum ogranicza badanie trybu podejmowania decyzji co do treści i form ,propagandy bezprawia”. Stawiając sobie to zadanie badawcze, Autor znakomicie pokazuje wielowątkowość podstawowego problemu oraz przeplatanie się tych wątków. Wychodzi od kwestii, jakie informacje trafiały do środków masowego przekazu, z preferencją dla materiałów filmowych. Tu będą miały się znaleźć zarówno informacje o wprowadzaniu w życie nowych aktów prawnych tworzących wszak nową rzeczywistość w stosunku do prawa II RP, a także lat okupacji, jak i relacje z procesów sądowych. Autor ma na uwadze także materiał mający zdelegalizować państwo i prawo II RP oraz przedstawić je w najciemniejszych barwach, skontrastowany z wiadomościami o nowym prawie. Tym prawie, które - jak to Jacek Kaczmarski ujął w Opowieści pewnego emigranta - w znacznym stopniu przyniesione było ze Wschodu: „Ja byłem jak Mojżesz, niosłem Prawa Nowe,/ Na których się miało oprzeć Odbudowę".

1 J. Kuisz, Propaganda bezprawia. O „,popularyzowaniu prawa” w pierwszych latach Polski Ludowej, Wydawnictwo Naukowe Scholar, Warszawa 2020, ss. 433. 
Jarosław Kuisz podjął się zadań komparatystycznych przez porównywanie tych samych wiadomości prezentowanych w materiałach audiowizualnych, prasie codziennej oraz fachowych czasopismach prawniczych. Jako kolejne zadanie badawcze Autor postawił poszukiwanie odpowiedzi na pytanie, w jaki sposób „opowiadano obrazem” o normach prawnych (s. 28). To bardzo ciekawe naukowo zagadnienia i w zakresie prawa pionierskie.

Były dwie główne instytucje zajmujące się w początkach Polski Ludowej propagandą prawa. Ministerstwo Sprawiedliwości używało w tej materii metod tradycyjnych (wykłady, konferencje, prasa, komunikaty radiowe oraz przez głośniki). Ministerstwo Informacji i Propagandy zawiadywało zaś środkami audiowizualnymi, wśród których na czoło wybijała się Polska Kronika Filmowa, a dalej filmy, zwłaszcza dokumentalne. Autor ma świadomość, ale warto chyba podkreślić, że propaganda audiowizualna była charakterystyczna dla systemów totalitarnych od Mussoliniego poczynając, poprzez Goebbelsa, na Stalinie bynajmniej nie kończąc. Wzory wschodnie mają tu zaś podstawowe znaczenie.

Wychodząc znacznie poza zakres omawianej pracy Jarosława Kuisza, warto czytelnikowi tych słów przybliżyć owe wzory wschodnie. Trzeba przyznać rację znawcom historii filmu światowego, że od pierwszych miesięcy po rewolucji październikowej „bolszewicy widzą w filmie ważną broń ideologiczną, zgodnie ze słowami Włodzimierza I. Lenina: »Sztuka filmowa jest dla nas najważniejszą ze wszystkich sztuk «"2. Radziecka produkcja filmowa to początkowo kroniki tygodniowe, ale już we wrześniu 1919 r. powołano w Moskwie Wyższą Szkołę Filmową. Jeden z pierwszych (1921) sowieckich filmów pełnometrażowych to agitka w służbie rewolucji pt. Sierp i młot, a nie brakuje dzieł wybitnych, jak tryptyk rewolucyjny Siergieja Eisensteina: Strajk(1924), Pancernik Potiomkin (1925), nakręcony na zamówienie dla uczczenia rocznicy rewolucji 1905 r., który to film wszedł na zawsze do historii światowej kinematografii (m.in. scena na schodach) i niektórzy uważają go za najlepszy film w dziejach³, oraz Październik (1927), wyświetlany z przedmową Lenina ${ }^{4}$. Już w 1929 r. Eisenstein nakręcił Stare i nowe, film agitacyjny poświęcony kolektywizacji wsi sowieckiej, a w latach późniejszych dwuczęściową epopeję historyczną Iwan Groźny, którego to filmu przestraszył się sam Wódz Generalissimus Stalin, obawiając się swojego konterfektu krwawego cara $^{5}$. W bolszewickiej kinematografii wczesnego okresu, ale i później, znalazło się

${ }^{2}$ Kronika filmu, oprac. zespół pod kierunkiem M.B. Michalika, Warszawa 1995, s. 44.

3 J. Płażewski, Historia filmu dla każdego (1895-1980), Warszawa 1986, s. 44; J.F. Lewandowski, J. Słodowski, 100 filmów, które powinniście obejrzeć, jeśli znajdziecie okazję, Katowice 1994, s. 18.

${ }^{4}$ https://archive.org/details/Eisenstein-October [dostęp: 21.09.2021].

${ }^{5}$ Za część pierwszą Siergiej Eisenstein otrzymał Nagrodę Stalinowską, ale (4.09.1946 r.) zakazano rozpowszechniania drugiej części, gdyż Stalin obawiał się, iż widzowie mogliby się trafnie doszukiwać analogii między krwawym despotą Iwanem Groźnym a Józefem Wissarionowiczem. 
wielu twórców wybitnych, jak choćby Siergiej i Gieorgij Wasiljewowie, tworzący „dla praktycznych celów politycznych [...] wierząc, że sztuka i polityka to jedno"6.

Audiowizualna propaganda prawa w omawianej monografii wybija się zdecydowanie na pierwszy plan, ale prezentacji i analizie poddane zostały również inne akcje propagandowe, stosowane przez Ministerstwo Sprawiedliwości. W tym kręgu autor zaprezentował m.in. akcję prasową, działania podejmowane przez komisje popularyzacji prawa, działalność wydawniczą, radiową popularyzację prawa, wizytacje ministerialne, a także przedstawił jako infrastrukturę - struktury organizacyjne Ministerstwa Sprawiedliwości, ze szczególnym uwzględnieniem Departamentu Szkolenia Zawodów Prawniczych i Popularyzacji Prawa.

Książka obejmuje lata 1944-1947, czego zabrakło w tytule monografii. O ile termin a quo - ogłoszenie Manifestu PKWN - nie powinien budzić wątpliwości (chociaż autor zgłasza pewne zastrzeżenia na temat skąpej ilości materiałów archiwalnych), o tyle koniec 1947 r. (grudzień) wymaga uzasadnienia. Można wszak zapytać, dlaczego nie przyjąć jakże ważnego grudnia 1948 r. na czele z sierpniowo-wrześniowym plenum PPR, na którym - według ówczesnego żargonu politycznego - ,zdemaskowano i rozgromiono odchylenie prawicowo nacjonalistyczne w partii". Wszyscy wiemy, że ówczesne partyjne zmiany kadrowe pociągały za sobą pogłębienie i przyspieszenie stalinizacji Polski i w dużym stopniu dotyczyło to także prawa, m.in. sprawa tworzenia kodeksu cywilnego i liczne inne. Odnosi się to również do serii dramatycznych represji dokonywanych przez organy ścigania, prokuratury i sądy, zwłaszcza wojskowe, realizowanych w trybie procesów sądowych po części tajnych, po części pokazowych. Nie należy zapominać o likwidacji pierwszej (sic!) partii robotniczej - PPS, likwidacji nazwanej eufemistycznie zjednoczeniem partii robotniczych (15 grudnia 1948 r.). Najznakomitsi znawcy - historycy prawa - badający po upadku komunizmu dzieje prac nad kodeksem cywilnym Polski zgodnie twierdzą, że to koniec 1948 r. stanowił zdecydowaną cezurę - zwrot w pracach nad prawem cywilnym. „W dniu 15 grudnia $1948 \mathrm{r}$. [...] przewodniczący obradom Komisji S. Szer nawiązał do rozpoczynających się w Warszawie obrad kongresu zjednoczeniowego PPR i PPS" i członkowie Komisji, zdając sobie sprawę z zachodzących zmian, odeszli od wcześniejszych założeń prac, zaś ostateczne przerwanie prac nad kodyfikacją nastąpiło w połowie 1949 r. „Dyrektywa H. Minca oznaczała, iż należy jak najszybciej przystąpić do tworzenia nowego socjalistycznego prawa"7. Podobnie ,przełomowe zmiany w pracy Komisji Kodyfikacyjnej Prawa Cywilnego" w grudniu 1948 r. konstatuje Anna

Kronika filmu, s. 193; J.F. Lewandowski, J. Słodowski, 100 filmów..., s. 56; Z. Pitera, Leksykon reżyserów filmowych. Reżyserzy zagraniczni, Warszawa 1984, s. 101.

${ }^{6}$ A. Jackiewicz, Moja filmoteka. Film w kulturze, Warszawa 1989, s. 159; idem, Moja filmoteka. Literatura i teatr w filmie, Warszawa 1989, s. 248 i n.

7 P. Fiedorczyk, Unifikacja i kodyfikacja prawa rodzinnego w Polsce (1945-1964), Białystok 2014, s. 146-147. 
Moszyńska ${ }^{8}$. „Przesilenie na sierpniowo-wrześniowym plenum KC PPR oznaczało drastyczną zmianę kursu politycznego. [...] Obowiązkowe przeszczepianie wzorców radzieckich miało także objąć prawo cywilne, któremu wyznaczono aktywną rolę w budowie ustroju socjalistycznego. Oczekiwań tych nie spełniał opracowany w latach 1947-1949 pierwszy projekt kodeksu cywilnego. Dalsze prace kodyfikacyjne zostały przerwane [...]"9. Analogicznie było z zaawansowanymi przygotowaniami kodeksu pracy - na posiedzeniu 22 lutego 1949 r. odwoływano się do wzorów radzieckich, jednak pomysł uwzględnienia w kodeksie aspektu współzawodnictwa pracy został odrzucony i było to ostatnie posiedzenie Komisji ${ }^{10}$. Od jesieni 1948 r. zaczęły się aresztowania, śledztwa, a później procesy polityczne działaczy partyjnych oraz oficerów Wojska Polskiego. Najpierw (13 października 1948 r.) aresztowano Włodzimierza Lechowicza ${ }^{11}$, a potem jeszcze około stu osób spośród działaczy partyjnych. 24 lutego 1949 r. Sekretariat Komitetu Centralnego PZPR powołał Komisję Biura Politycznego do Spraw Bezpieczeństwa Publicznego na czele z Bierutem, Bermanem i Radkiewiczem. Sprawy te i ich dalszy rozwój są ogólnie znane i mają już swoją literaturę ${ }^{12}$; to wówczas powołano sławetny X Departament MBP. Równolegle zaczęły być prowadzone przez Informację Wojskową aresztowania i śledztwa oficerów Wojska Polskiego, głównie oficerów przedwojennych; w 1947 r. Informacja WP aresztowała 830 osób i aresztowania trwały dalej, a po skrajnie brutalnych śledztwach poszły sfingowane procesy i drastyczne wyroki. Sprawy te są ogólnie znane i mają dzisiaj bogatą literaturę ${ }^{13}$.

To sądy wojskowe, zwłaszcza Wojskowe Sądy Rejonowe (WSR-y), w większości odpowiedzialne są za crimina laesae iustitiae (Witold Kulesza) - zbrodnie obrazy sprawiedliwości, zbrodnie sądowe. Witold Kulesza wykazał przerażającą determinację sędziów w karaniu, w dążeniu, by nie wypuścić oskarżonych wolnymi, by „znaleźć formalną podstawę dla wymierzenia kary śmierci”; „sędziowie działali z zamiarem zabójstwa oskarżonych"14. Dodajmy do tego wiadomości

${ }^{8}$ A. Moszyńska, Geneza prawa spadkowego w polskim kodeksie cywilnym z 1964 roku, Toruń 2019, s. 110.

${ }^{9}$ Ibidem, s. 138.

10 A. Giedrewicz-Niewińska, Projekt kodeksu pracy z 1949 r., Oświęcim 2015, s. 28.

${ }^{11}$ W. Lechowicz, Będziesz przeklinat ten dzień..., Warszawa 1989, s. 16.

12 Szerzej: R. Spałek, Komuniści przeciwko komunistom. Poszukiwanie wroga wewnętrznego w kierownictwie partii komunistycznej w Polsce w latach 1948-1956, Warszawa 2014, passim.

${ }_{13}$ Pionierskie są prace J. Poksińskiego, ,, TUN”. Tatar, Utnik, Nowicki. Represje wobec oficerów Wojska Polskiego w latach 1949-1956, Warszawa 1992 i kolejne wydania; idem, ,, My, sędziowie, nie od Boga...”. Z dziejów sądownictwa wojskowego PRL 1944-1956. Materiały i dokumenty, Warszawa 1996; zob. też: E. Romanowska, Karzace ramię sprawiedliwości ludowej. Prokuratury wojskowe w Polsce w latach 1944-1955, Warszawa 2012, s. 218, passim.

${ }^{14}$ W. Kulesza, Crimen laesae iustitiae. Odpowiedzialność karna sędziów i prokuratorów za zbrodnie sadowe wedtug prawa norymberskiego, niemieckiego, austriackiego i polskiego, Łódź 2013, s. 318-324; zob. też recenzję A. Lityńskiego w „Czasopiśmie Prawno-Historycznym” (CPH) 2014, z. 2, s. 369 i n. Por. K. Siemaszko, , W trudnym okresie odbudowy państwa”. Tak zwany maty 
o zdarzeniach wykazujących determinację do wykonania aktu zabójstwa ${ }^{15} .,[\ldots]$ kto pokładał ostatnią nadzieję w instytucjach prawa musiał doświadczyć tego, że każda z tych instytucji zwracała się przeciwko niemu, stanowiąc część sieci terroru i gnębienia"16. Te głębokie i bardzo smutne słowa Amerykański Trybunał Wojskowy wypowiedział i zapisał w wyroku z 4 grudnia 1947 r. w sprawie prawników nazistowskich.

Autor z gruntowną znajomością realiów politycznych tamtych lat swoje uzasadnienie terminu ad quem wykłada czytelnikowi, pisząc, że „dla historyków prawa to moment, w którym zakończył się w Polsce Ludowej okres traktowany jako przejściowy" (s. 24). Rzeczywiście: sfałszowane wybory do Sejmu Ustawodawczego w styczniu 1947 r. i tzw. mała konstytucja z 19 lutego 1947 r., wręcz fizyczne zlikwidowanie formalnie jeszcze legalnie działającej opozycji politycznej (PSL), czego kulminacyjnym momentem była potajemna emigracja Stanisława Mikołajczyka. Autor jeszcze dodaje (s. 25) oficjalne zlikwidowanie (11 kwietnia 1947 r.) istniejącego od chwili utworzenia PKWN Ministerstwa [najpierw Resortu]

kodeks karny w świetle orzecznictwa Sąu Okręowego w Krakowie w latach 1946-1950, Warszawa 2015, s. 75-76; M. Paszek, Odpowiedzialność sędziów Wojskowego Sadu Rejonowego w Katowicach za zbrodnie sadowe (1946-1955), CPH 2015, z. 2, s. 205-208, passim; D. Maksimiuk, , Winni zbrodni”? - o próbach rozliczenia , stalinowskich” prokuratorów w latach 1956-1958, „Z Dziejów Prawa" 2012, t. 5(13), s. 323-337.

${ }^{15}$ Znamy przypadek, gdy kobieta (Anna Krużołek) została skazana - przy braku jakichkolwiek dowodów - przez Wojskowy Sąd Rejonowy w Katowicach na karę śmierci za ukrywanie poszukiwanego przez bezpiekę. Najwyższy Sąd Wojskowy wyrok ten uchylił, ale katowicki sędzia wojskowy nakazał wyrok śmierci wykonać i kobietę rozstrzelano. Protokót narady partyjnej aktywu partyjnego Najwyższego Sądu Wojskowego [...20-21 listopada 1956] [w:] J. Poksiński, ,, My, sędziowie, nie od Boga...", s. 171; M. Paszek, Odpowiedzialność sędziów..., s. 205-206; eadem, Wojskowy Sad Rejonowy w Katowicach (1946-1955). Organizacja i funkcjonowanie, Katowice - Warszawa 2019, s. 323 [monografia będąca pracą doktorską napisaną pod kierunkiem A. Lityńskiego, która otrzymała I nagrodę na najlepsze prace doktorskie za rok 2017 w konkursie organizowanym przez Instytut Wymiaru Sprawiedliwości w Warszawie; Marta Paszek zadedykowała ją zamordowanej Annie Krużołek]. Wskazywałem już kiedyś, że analogiczną determinację w pozbawieniu człowieka życia widać w kazusie wykonania wyroku na Szmulu Ehrenreichu, starym człowieku, który uniknął Holocaustu, w trybie doraźnym skazanym za przestępstwo walutowe na karę śmierci w 1952 r. Wówczas to, w cztery miesiące po uchwaleniu konstytucji PRL (22 listopada 1952 r.), władze zaplanowały ogłosić z okazji konstytucji amnestię. „Prośba o łaskę została odrzucona 20.XI.1952 r., tego samego dnia Generalna Prokuratura odesłała akta sprawy do sądu i tego samego dnia uzyskała z Sądu Wojewódzkiego potrzebne do wykonania wyroku dokumenty. Tego samego dnia 20.XI.1952 r. został Ehrenreich stracony na dwa dni przed uchwaleniem ustawy o amnestii z dnia 22.XI.1952 r.”. Sprawozdanie Komisji dla zbadania działalności tzw. , sekcji tajnej” Sądu Wojewódzkiego dla m.st. Warszawy, Archiwum Akt Nowych w Warszawie [AAN], zespół Prokuratura Generalna PRL [Prok. Gen.], sygn. 950, s. 51. Niedawno M. Zaborski z udziałem E. Romanowskiej wydali obszerny tom ważnych dla tego tematu dokumentów archiwalnych: Wimię przyszłości Partii. Procesy o łamanie tzw. praworzadności socjalistycznej 1956-1957. Dokumenty, Warszawa 2019.

${ }^{16}$ Amerykański Trybunał Wojskowy w wyroku z 4 grudnia 1947 r. w sprawie prawników; cyt. za W. Kuleszą, Crimen laesae iustitiae..., s. 40. 
Informacji i Propagandy oraz podsumowanie akcji propagandowej (grudzień 1947 r.) w Ministerstwie Sprawiedliwości. Były to wydarzenia tak ważne, że uzasadniają zakończenie tej bogatej w treści monografii z końcem 1947 r.

Jarosław Kuisz jednak nieraz przekracza wyznaczoną sobie cezurę końcową - rok 1947, (wyjątkowo sięgając nawet znacznie dalej, bo do czasu po śmierci Stalina), lata 1948-1950 to czas, kiedy popularyzatorskie kampanie prawa stają się coraz bardziej polityczne, jak np. akcje pogłębiania przyjaźni polsko-radzieckiej pod auspicjami Ministerstwa Sprawiedliwości, akcje związane z realizacją planu sześcioletniego czy nawet akcje niekoniecznie dotyczące prawa (np. akcja żniwna). Recenzent jako ciekawostkę może tu przypomnieć (pisał już bowiem o tym), że referujący w lipcu $1950 \mathrm{r}$. w sejmie projekt nowej, ważnej ustawy o prokuraturze Leon Chajn (oprócz cytowania Lenina i Bieruta) wyliczał dotychczasowe osiągnięcia prokuratury m.in. w tych słowach: „Prokuratura wpłynęła na właściwe czyszczenie i sortowanie ziemniaków, na koordynowanie podstawiania wagonów, na urealnienie sprawozdawczości, na wzmożenie poczucia odpowiedzialności osób odpowiedzialnych za realizację przerzutów ziemniaków”"17. Wolny rynek sam to załatwia, natomiast w scentralizowanym systemie totalitarnym akcją żniwną i sortowaniem ziemniaków trzeba obarczać prokuraturę, bo też w systemie tym głównym narzędziem państwa jest prawo karne oraz represje pozaprawne. Sejmowa dyskusja była „dyskusją” w cudzysłowie, tak jak cały ówczesny sejm był w istocie atrapą parlamentu.

Zgłoszone przeze mnie sygnały dotyczące terminu ad quem kierują uwagę na zagadnienia związane z kodyfikacją zwłaszcza prawa cywilnego oraz na represje $\mathrm{w}$ istocie natury politycznej realizowane przy pomocy organów ścigania oraz sądów. Część tych wydarzeń, o których wspomniałem, nie tylko nie nadawała się do „popularyzacji prawa”, ale była wręcz utajniona, a część procesów także odbywała się w utajnieniu, chociaż inne przeciwnie - były nagłaśniane, traktowane jako pokazowe. W każdym razie recenzent chce powtórzyć (pisał o tym wielokrotnie), iż komunizm jest najbardziej zakłamanym systemem w dziejach ludzkości. Nigdy i nigdzie nie było takiej rozbieżności między głoszonymi ideami, hasłami, oświadczeniami, prawem na papierze a ,rzeczywistą rzeczywistością", w przeciwieństwie do „,rzeczywistości urojonej” (Franciszek Ancewicz). „Totalne kłamstwo” (Leszek Kołakowski) to jedna z istotnych cech tego systemu. W to kłamstwo wpisywało się „wymierzanie sprawiedliwości”, będące głównie realizacją totalitarnego terroru. W zasadzie każdy unicestwiany w tym systemie (wszak z góry przewidziany do unicestwienia) miał wyrok: nie zabijało się człowieka bez wyroku. To wpisywało się w charakterystyczną cechę komunistycznego totalitaryzmu - totalne kłamstwo. Tym różnił się totalitaryzm czerwony od brunatnego; ten ostatni nie ukrywał swoich

17 Sprawozdanie stenograficzne z 84 posiedzenia Sejmu Ustawodawczego w dniach 20 i 21 lipca 1950 r., Warszawa 1950, s. 27, 31; zob. też: A. Lityński, Historia prawa Polski Ludowej, Warszawa 2013, s. 80. 
celów i wysyłał miliony osób na śmierć, nie potrzebując do tego sądowych wyroków. W systemie komunistycznym niemal wszyscy represjonowani mieli śledztwo (z torturami) i procesy. Dla represji politycznych uruchamiano prawo karne oraz procedury śledcze i sądowe; niemal każdy „likwidowany” miał wyrok orzekający, że jest strasznym zbrodniarzem. To element komunistycznej fikcji i zakłamania: nie represjonowano niewinnych, tylko zbrodniarzy. Tak było od początku, ale to zwłaszcza ,stalinizm, w miarę umacniania się totalitarnego oblicza systemu, coraz bezczelniej poszerzał przepaść między fasadą polityczną i rzeczywistością"18. Autor omawianej monografii krótko nawiązuje do tych problemów.

Autor wykazuje się imponującą erudycją w materii i literaturze naukowej polskiej i zagranicznej - w materii dotyczącej rozwoju badań nad historią i filmem oraz ich związkami. To problem kultury, naszej światowej kultury człowieka cywilizowanego. Autor zgodnie z poglądami uczonych zachodnich wyodrębnia trzy okresy oddziaływania różnych mediów na odbiorców: okres papieru (18481916), filmu (1916-1960) i telewizji (po 1960 r.). Pierwsze lata Polski Ludowej przypadają zatem na okres rozwoju kinematografii. Narzucony po 1944 r. przez ludobójczego totalitarnego wschodniego zaborcę system ustrojowy ukształtował Polskę jako organizm niesuwerenny, a jedynie z dużą dozą autonomii; bez porównania jednak większą niż radzieckie republiki ZSRR. Stopniowo wywracano wszystko, co w jakże trudnym dwudziestoleciu Polacy i obywatele polscy stworzyli. Jarosław Kuisz z właściwą sobie werwą pisarską i umiejętnością stawiania oraz kontrastowania problemów napisał: „W zdewastowanym II wojną światową kraju jakakolwiek próba upowszechniania wiedzy o prawie mogła wydawać się, eufemistycznie rzecz ujmując, ekstrawagancją. To okres, w stosunku do którego w nauce zadaje się przecież pytanie, czy mamy do czynienia $\mathrm{z}$ »wojną domową czy nową okupacjąu (by odwołać się do tytułu książki pod redakcją Andrzeja Ajnenkiela)" (s. 18). Warto tutaj przytoczyć na ten temat zdanie takiego autorytetu, jakim jest Adam Strzembosz, który na pytanie zawarte w tytule książki pod redakcją Andrzeja Ajnenkiela odpowiedział: „państwo polskie mające legalne władze na emigracji i w kraju stało się pod koniec II wojny światowej przedmiotem agresji ze strony Związku Sowieckiego, której następstwem była okupacja wojenna całego terytorium na zachód od linii Bugu, a aneksja - na wschód od tej granicy". Aneksja została uznana przez zachodnich aliantów, zaś stan okupacji był milcząco tolerowany, jako konsekwencja podziału na strefy wpływów. Państwo polskie więc „było tworem niesuwerennym”"19.

18 J. Baszkiewicz, Powszechna historia ustrojów państwowych, Gdańsk 1998, s. 356 (podkr. w oryginale).

19 A. Strzembosz, Okupacja w prawie międzynarodowym a status prawny Polski $w$ latach 1944-1956 [w:] A. Ajnenkiel (red.), Wojna domowa czy nowa okupacja? Polska po roku 1944, Wrocław - Warszawa - Kraków 1998, s. 25-26. 
Wszyscy wiedzieli, ze Stalinem na czele ${ }^{20}$, że gdyby nie teherański podział świata między mocarstwami iobecnośćnaziemiach polskichArmiiCzerwonejzjejNKWD-owskim zapleczem, komuniści w Polsce nie utrzymaliby się przy władzy nawet kilka dni. Może warto zasygnalizować: znany w literaturze naukowej ,rugatielnyj razgawor" Stalina z komunistami mającymi z jego nadania władać Polską, odbyty na Kremlu na przełomie września i października 1944 r., w okresie bezpośrednio poprzedzającym konferencję radziecko-brytyjską (Stalin - Churchill) oraz rozmowy polsko-,,polskie" (Mikołajczyk - PKWN). Wydarzenie tak oto podsumował Gomułka: „Musieliśmy więc dokonać gwałtownego zwrotu na tym odcinku działalności partii i PKWN. Ze zrozumiałych względów prawdziwe przyczyny tego zwrotu nie mogły być ujawnione. Znało je tylko wąskie grono ludzi z centralnego kierownictwa partii" ${ }^{21}$.

Niedawno wydany został w języku polskim (wkrótce po wydaniu oryginału w języku rosyjskim, 2016) dokument - źródło najwyższej wagi z historii polsko-sowieckich wydarzeń od 17 września 1939 r. do ostatecznej pacyfikacji Polski po zakończeniu wojny w Europie: Tajemnice walizki generała Sierowa. Dzienniki pierwszego szefa KGB. 1939-196322. Są to prowadzone w zasadzie na bieżąco przez niemal ćwierć wieku zapiski-pamiętniki szefa sowieckiej bezpieki, a później sowieckiego wywiadu wojskowego ${ }^{23}$ GRU, „Iwana Groźnego”, jak nazwała go brytyjska prasa, gdy kiedyś służbowo przybył do Wielkiej Brytanii. Sierow zaczął od sowietyzacji ziem II Rzeczypospolitej włączonych do Ukraińskiej SRR po 17 września 1939 r. Chruszczow wspominał: „Sierow z racji sprawowanej funkcji nawiązał wtedy służbowo kontakty z gestapo. Na mocy porozumienia z Niemcami

${ }^{20}$ Protokót z posiedzenia KC dnia 9 października 1944 r. [w:] Dokumenty do dziejów PRL, z. 2: Protokoty posiedzeń Biura Politycznego KC PPR 1944-1945, oprac. A. Kochański, Warszawa 1992, s. 16 i n.; Protokól z posiedzenia Biura Politycznego PPR, „Zeszyty Historyczne” 1990, z. 91 (Jak Stalin rozpętał wojnę domowa w Polsce w 1944 r. Dekret o ochronie państwa z 30 października 1944 r.), s. 190-198. Bierut miał jeszcze powtórzyć następujące słowa Stalina: „Jak tak patrzę na waszą pracę, to - gdyby nie było Armii Czerwonej - to przez tydzień was nie byłoby" (ibidem, s. 192); także W. Gomułka, Pamiętniki, red. A. Werblan, t. 2, Warszawa 1994, s. 471. Wydarzenie to od dawna ma już swoją literaturę, zob. A. Lityński, O prawie i sądach początków Polski Ludowej, Białystok 1999, s. 79 i n.; idem, Historia prawa Polski Ludowej, Warszawa 2013, s. 116.

${ }^{21}$ W. Gomułka, Pamiętniki, t. 2, s. 471; K. Kersten, Terror na przełomie wojny i pokoju. Lipiec 1944 - lipiec 1945, „Aneks” 1988, s. 101, passim; A. Lityński, O prawie i sądach początków Polski Ludowej, Białystok 1999, s. 79.

${ }^{22}$ Tajemnice walizki generała Sierowa. Dzienniki pierwszego szefa KGB. 1939-1963, red. A. Hinsztejn, thum. A. Janowski, J. Cichocki, Konstancin-Jeziorna 2019, s. 863. Aleksandr Hinsztejn - członek Centralnej Rady Rosyjskiego Towarzystwa Wojskowo-Historycznego - przygotował wydanie rosyjskie. Każdy rozdział poprzedził zwięzłym komentarzem historycznym, a także opatrzył przypisami.

${ }^{23}$ Warto zauważyć, że Sierow jako jedyny w Związku Radzieckim był szefem zarówno „cywilnego" Komitetu Bezpieczeństwa Państwowego (KGB - Комитет Государственной Безопасности, Komitiet Gosudarstwiennoj Biezopasnosti), jak i wojskowego Głównego Zarządu Wywiadu (GRU - Главное Разведывательное Управление, Gławnoje Razwiedywatielnoje Uprawlenije). 
we Lwowie ulokowała się oficjalna agentura gestapo. Nie wiem dokładnie, jak liczna była sieć agentów, ale działało ich dużo"24. Sierow tu milczy. Bardzo sprawny i mający od 17 września 1939 r. doświadczenie w represjonowaniu Polaków generał Sierow został pełnomocnikiem NKWD 1. Frontu Białoruskiego, czyli został odkomenderowany do zajmowania się wyłącznie pacyfikacją Polski, gdy upadło powstanie warszawskie. Sierow został pełnomocnikiem NKWD nie przy PKWN, lecz „doradcą” przy polskim Ministerstwie Bezpieczeństwa Publicznego (MBP). Polecenie Stalina i przelot Sierowa do Lublina wiąże się ze znanym pobytem (28 września - 3 października 1944 r.) delegacji KRN i PKWN (faktycznie PPR) w Moskwie i wspomnianym tutaj ,rugatielnym razgaworem” Stalina, a w rezultacie z tzw. zwrotem październikowym polegającym na zaostrzeniu terroru. Do jednej z grup operacyjnych Sierowa został odkomenderowany Józef Światło; lubili się se $^{25}$. To Sierow kierował pacyfikacją Polski.

Autor monografii Propaganda bezprawia ... znakomicie splata wątki czysto prawnicze $\mathrm{z}$ wątkami historyczno-politycznymi przenosząc czytelnika w tamte czasy. Cała praca napisana jest ładnym językiem i obrazowo, co jest ważne zawsze, ale w tym przypadku tym bardziej że po większej części dotyczy obrazu w filmie. To nie tylko praca $\mathrm{z}$ historii prawa, ale także dzieło z zakresu kulturoznawstwa, dokładniej historii kultury prawnej. Problemy prawa w tekstach kultury to zagadnienia nader ważne dla kultury ludzkiej. Poruszając zagadnienie prawa w tekstach kultury, Autor trafnie przypomina, że jednym z pionierów w literaturze polskiej był prof. Witold Maisel i jego dzieło Archeologia prawna Polski (1982).

Materiały audiowizualne będące głównym tworzywem monografii Propaganda bezprawia ... zostały przez Autora opracowane metodą historyczną (przy modyfikacjach wynikających ze specyfiki źródła): zastosowano więc opis i ówczesne znaczenie prawne wraz z naukową krytyką nam współczesną. W przypadku filmu (kroniki filmowej) Autor brał pod uwagę zarówno materiał filmowy, jak i tekst czytany przez lektora. Nie zajmował się natomiast procedurą przygotowywania materiałów oraz trybem podejmowania decyzji. Zważywszy na ogrom materiału, zarówno historycznego, jak i teoretycznego, takie ograniczenie jest uzasadnione. Praca jest bardzo bogata w treść.

Przechodząc do wybranych kwestii, można zauważyć, że Jarosław Kuisz dość obszernie przedstawia organizowanie i przebieg zdarzeń w zakresie popularyzowania nowego prawa małżeńskiego. Jak się dowiaduje czytelnik (s. 131 i n.), w Ministerstwie Sprawiedliwości pierwszy kurs dla prelegentów terenowych, przeprowadzony 20 grudnia 1945 r., dotyczył właśnie nowego prawa małżeńskiego, a ściśle treści dekretu z 25 września 1945 r. o prawie małżeńskim. Była to dopiero pierwsza część zakrojonej na szeroką skalę pracy popularyzatorskiej. Zważywszy,

${ }^{24}$ N.S. Chruszczow, Fragmenty wspomnien, „Zeszyty Historyczne” 2000, z. 132, s. 123.

${ }_{25}$ Z. Błażyński, Mówi Józef Światto. Za kulisami bezpieki i partii 1940-1955, wstęp J. Nowak-Jeziorański, Londyn 1986, s. 60-61. 
że nowe prawo małżeńskie osobowe, znacznie różniące się od dotychczasowego, wchodziło w życie 1 stycznia 1946 r., sprawa musiała być traktowana jako nadzwyczaj pilna i popularyzacja została zorganizowana w pośpiechu. Autor przytacza pełną treść audycji radiowej poprowadzonej w formie dialogu pt. „Rozwód”. Zwraca uwagę recenzenta, że ani w tej audycji, ani w innym materiale prezentowanym przez Jarosława Kuisza nie znajdujemy sygnałów, jak bardzo zmieniło się to prawo. Omówił te sprawy dokładnie Piotr Fiedorczyk ${ }^{26}$, począwszy od prac nad projektami dekretu, kiedy to już wystąpił problem ,zerwania z kościelnym postulatem nierozerwalności małżeństwa i zastąpieniem go zasadą trwałości, która oznaczała jednak dopuszczenie możliwości rozwodu w razie zaistnienia określonych przesłanek”. Rząd w akcji propagandowej posłużył się argumentem skutków wojny dla rodzin jako uzasadnieniem dopuszczalności rozwodu. Kampania propagandowa w oficjalnej prasie odwoływała się do niezrozumiałego dla części społeczeństwa hasła „świeckości prawa małżeńskiego”. Argumentem za rozwodami miała być krytyka dogmatów katolickich o nierozerwalności węzła małżeńskiego. „Nie ma w świecie świętości takiego Sakramentu, który miałby prawo przykuć żołnierza spod Lenino czy Tobruku do kochanki niemieckiego gestapowca. Albo nawet kobietę, która przeniosła cały ciężar lat wojny i okupacji do człowieka wracającego do domu z chorobą weneryczną zamiast ran i odznaczeń" - pisał w sierpniu 1945 r. jeden z dzienników lokalnych ${ }^{27}$. Piotr Fiedorczyk i Zdzisław Zarzycki ${ }^{28}$ zgodnie stwierdzają, że dekret z 25 września 1945 r. uregulowany został według konstrukcji Karola Lutostańskiego sprzed wojny (1929 r.); dotyczy to także rozwodu wspartego nie na zasadzie nierozwiązywalności, lecz na zasadzie trwałości węzła małżeńskiego. Ponadto dekret wprowadzający prawo małżeńskie zawierał dwa „wojenne" przepisy rozwodowe, stanowiące wyjątki od zasady trwałości małżeństwa. Art. XII tego dekretu pozwalał na rozwiązanie małżeństwa przez rozwód, jeżeli jeden z małżonków wpisał się w czasie okupacji na niemiecką listę narodową. Była to jedyna, w pełni wystarczająca przesłanka rozwodu, nieistotne było tutaj nawet dobro małoletnich dzieci. Ratio legis tego przepisu opierało się więc na tezie szkodliwości społecznej utrzymywania związków małżeńskich z osobami narodowości niemieckiej. Szczególnej natury wyjątek został przewidziany w art. XIII przepisów wprowadzających. Zgodnie z jego treścią można było na zgodny wniosek stron, bez orzekania o winie, rozwiązać przez rozwód każde małżeństwo pod warunkiem, że trwało trzy lata. Prawo to miało charakter wyjątkowy, gdyż obowiązywało tyl-

${ }^{26}$ Interesujące są pionierskie ustalenia w przedmiocie tworzenia projektu oraz jego treści P. Fiedorczyka, Unifikacja i kodyfikacja prawa rodzinnego w Polsce (1945-1964), Białystok 2014, s. 39 i n.

${ }^{27}$ Ibidem, s. 41 i n.; P. Fiedorczyk [w:] P. Fiedorczyk, A. Lityński, A. Stawarska-Rippel, Wojny XX wieku i ich skutki dla ustrojów państwowych i prawa, CPH 2019, z. 1, s. 90.

${ }^{28}$ Z. Zarzycki, Rozwód w świetle akt Sądu Okręgowego w Krakowie w latach 1918-1945. Studium historyczno-prawne, Kraków 2010, s. 108 i n. 
ko w ciągu trzech lat po wejściu w życie dekretu, tj. do 31 grudnia 1948 r. Samo jednak jego istnienie należy uznać za wielki eksperyment społeczny, gdyż niemal bez ograniczeń pozwalało na rozwiązanie wcześniej zawartych małżeństw. Ustawodawca wyjaśniał, że celem przepisu jest likwidacja faktycznie nieistniejących małżeństw i uporządkowanie stanu cywilnego osób, którym wojna pokrzyżowała życie; utrzymywanie fikcji jest sprzeczne ze społecznymi celami rodziny. Był to najbardziej radykalny przepis o rozwodzie w polskim ustawodawstwie do dziś, a problem jego stosowania oczekuje na zbadanie"29.

Inną kwestią, która zwraca uwagę czytelnika, jest to jak dużo „propaganda prawa" poświęciła ówcześnie sprawie upowszechnienia informacji o amnestii z 22 lutego 1947 r. Ustawa amnestyjna z 1947 r. poza złagodzeniem kar za niektóre przestępstwa puszczała w niepamięć i wybaczała udział w przestępczym związku i przestępstwa popełnione $\mathrm{w}$ granicach działania tego związku, pod warunkiem że sprawca dobrowolnie w ciągu 2 miesięcy zaniecha działalności i zgłosi to organom bezpieczeństwa albo specjalnej komisji złożonej z przedstawicieli władz bezpieczeństwa i rady narodowej, co oczywiście było odnotowywane i rejestrowane przez resort bezpieczeństwa. Ustawa amnestyjna z $1947 \mathrm{r}$. stworzyła podstawę do ujawniania się „,celem umożliwienia wszystkim obywatelom wzięcia udziału w odbudowie Demokratycznej Polski Ludowej” (art. 1). Później - wbrew ustawie - wielu $\mathrm{z}$ ujawnionych aresztowano, skazywano i w inny sposób prześladowano. Ustawa amnestyjna została wykorzystana jedynie do zarejestrowania i ewidencjonowania ludzi podziemia, co miało już wkrótce ułatwić represje $\mathrm{e}^{30}$.

Propaganda prawa nie mogła pominąć wzbudzających duże zainteresowanie społeczne procesów przed Najwyższym Trybunałem Narodowym. Autor wkracza tu nieco dokładniej w strukturę i orzecznictwo tego sądu szczególnego i wskazuje m.in. na właściwość NTN. Szerzej pisze o odpowiedzialności hitlerowców, zaś krótko i tylko w przypisie (s. 321, przyp. 465) informuje, że do kompetencji NTN należały także ,sprawy o przestępstwa przewidziane w dekrecie z dnia 22 stycznia 1946 r. o odpowiedzialności za klęskę wrześniową i faszyzację życia państwowego (Dz. U. $1946 \mathrm{Nr} 5$, poz. 46)". Wypadałoby nieco szerzej poinformować czytelników o charakterze tego wyjątkowo ohydnego stalinowskiego aktu prawnego. Dekret miał zastosowanie wyłącznie do zachowań sprzed 1 września 1939 r., które wówczas nie były przestępstwami. Jak już kiedyś wskazywałem, przepisy dekretu tak sformułowano, że na ich podstawie można było skazać każdego urzędnika i oficera II Rzeczypospolitej, zwłaszcza wobec oficjalnie obowiązującej tezy o faszyzacji życia publicznego po 1926 r. oraz o wyłącznej odpowiedzialności sanacji za klęskę wrześniową. Dekret zawierał wiele nieostrych sformułowań pozwalających na dowolność interpretacyjną. Na podstawie przepisów tego dekretu został w $1953 \mathrm{r}$.

${ }^{29}$ P. Fiedorczyk, Unifikacja i kodyfikacja..., s. 146-147, tam dalsza literatura.

${ }^{30}$ A. Lityński, Historia prawa Polski Ludowej, Warszawa 2013, s. 121-122. 
oskarżony i skazany biskup Czesław Kaczmarek. Oskarżono go, „że jako wróg ludu polskiego, reakcjonista i zdecydowany zwolennik faszyzmu" działał zgodnie z wytycznymi polityki Watykanu. Dekret nad wyraz często stosowany był w sądach tajnych. Badająca po październiku 1956 r. sprawę sądów tajnych komisja ministerialna stwierdziła ściganie i skazywanie w sądach tajnych z tegoż dekretu ludzi, którzy zajmowali także niskie stanowiska służbowe (wykonywali tylko czynności techniczne, np. pisanie na maszynie), a z racji tego nawet nie orientowali się w całokształcie działalności instytucji, w której pracowali. Komisja stwierdziła porachunkowe stosowanie dekretu. Obowiązywał do 31 grudnia 1969 r. ${ }^{31}$ Najwyższy Trybunał Narodowy nie rozpoznał jednak ani jednej sprawy z dekretu o tzw. faszyzacji, zachowując tym samym czyste oblicze sądu.

Monografia Propaganda bezprawia ... oparta jest na wielkiej bazie literatury i źródeł, a erudycja Autora imponuje. Monografia ma dużą funkcję poznawczą. Bardzo ciekawa jest także konceptualizacja tak szerokiego materiału. Książka ma bowiem charakter interdyscyplinarny, co można uznać za zaletę - tym bardziej że w tym kierunku proponujemy kształcenie. Interdyscyplinarność skutkuje tym, iż nie można mówić o czystości metodologicznej, która przez niektórych badaczy stawiana jest na pierwszym miejscu. Piszący te słowa ma świadomość, że książka wywołała rozmaite, niekiedy skrajnie odmienne oceny w środowisku prawników. To skutek interdyscyplinarności. Aktualnie mamy różne podejścia do metodologii. Młodsi badacze zazwyczaj preferują podejście interdyscyplinarne i ono zyskało już swoje teorie. Zwłaszcza w badaniach nad szeroko rozumianą kulturą badania interdyscyplinarne mają głębokie uzasadnienie. Oczywiście istnieje też teoria kultury. Badacze mają wszak możliwość wyboru perspektywy oglądu materiału: albo historycznej, albo teoretycznej, albo antropologicznej. Rozprawa Jarosława Kuisza to nie tylko praca z historii prawa, ale także z zakresu kulturoznawstwa, dokładniej $-\mathrm{z}$ historii kultury prawnej. Problemy prawa $\mathrm{w}$ tekstach kultury to zagadnienia nader ważne dla kultury ludzkiej. Autor znakomicie splata wątki czysto prawnicze z wątkami historyczno-politycznymi, przenosząc czytelnika w tamte czasy.

W naukach humanistyczno-społecznych nie ma książki, która nie mogłaby być lepsza. Tylko w matematyce dwa razy dwa jest cztery i lepiej być nie może. Ale nauki społeczne nie są naukami ścisłymi, choć doceniam dążenia do ich uściślenia. Oceniający książkę może mieć inne oczekiwania i wyobrażenia co do meritum lub co do metody, ale recenzent powinien też uszanować prawo Autora do jego wyborów i konceptualizacji, zwłaszcza gdy dostrzega jej wartość. Jeśli jest inaczej, to może otworzyć drogę do polemiki lub do krytyki w przypadku błędów. Ja uważam pracę Jarosława Kuisza za dzieło wybitne i w zasadzie - w takim zakresie - pionierskie na polskim gruncie.

${ }^{31}$ Ibidem, s. 120-121. 